\title{
Perceived Barriers towards e-Learning by Faculty Members at a Recently Established University in Saudi Arabia
}

\author{
M. A. Al Gamdi and A. Samarji
}

\begin{abstract}
E-learning is nowadaysan essential teaching and learning setting to both faculty members and students in a digital and connected $21^{\text {st }}$ Century. Despite the attempts and the claims that many higher education institutes make in regards to e-learning, a number of barriers retard many faculty members to progress from the state of appreciating and acknowledging e-learning to the state of actually adopting and implementing it. Saudi higher education institutes and Saudi faculty members are no exception in facing such barriers. This paper investigated the challenges to adopting e-learning in higher education by focusing on one of the recently established Saudi universities as a case study. Quantitative data were collected through 214 questionnaires. Findings from quantitative data analysis revealed a number of barriers which challenge the effective implementation of e-learning at the targeted Saudi university. This paper found that barriers towards e-learning are gender-related. In addition, this paper reports that the most cited barriers were external sources barriers which suggests that strategic policies need to be in place to overcome such resources barriers. Once external sources barriers are overcome, focus can shift on the pedagogical opportunities that e-learning creates and makes possible. As e-learning is a developing field of interest in Saudi higher education institutes, this paper adds to the little literature conducted so far in a Saudi context. In addition, findings from this paper contribute to the global literature on e-learning in a globalised and connected world.
\end{abstract}

Index Terms-E-learning, Saudi Arabia, faculty members, and perceived barriers.

\section{INTRODUCTION}

Technological and Information Communication Technological innovations and advancements have had major impact on our day lives, with education being no exception. Such innovations and advancements have offered vast opportunities as well as challenges for organizations across various industries- including higher education institutes (HEIs)-in a way that all organizations are nowadays compelled to present and offer- in part or full- their services online.

During the last decade of $20^{\text {th }}$ century, the read-only Web1.0 technologies started impacting the higher education industry with the emergence of the term "e-learning". With the commencement of the 21 st century, the more interactive read-and-write Web 2.0 technologiesemerged in association

Manuscript received June 5, 2014; revised September 10, 2014.

M. A. Al Gamdi is with Victoria University, Australia (e-mail: mohammadali.algamdi@live.vu.edu.au).

A. Samarji is with College of Education, Victoria University, Australia (e-mail: ahmad.samarji@vu.edu.au,ahmad.samarji@live.vu.edu.au). with greater focus in higher education on student-centred teaching and learning practices. E-learning in higher education continues to develop with emerging technologies, bringing more opportunities for both the students and faculty staff members. However, e-learning requires considerable support not only from infrastructural and logistic perspectives, but also from a pedagogical and content perspectives, where technology is expected to be effectively integrated across the vast activities and teaching and learning transactions within higher education institutes (HEIs) through a holistic and well planned approach.

Nowadays, HEIs- worldwide- strive to cope with these technological innovations and to offer a teaching and learning environment for both students and faculty staff members which respond to a digital and connected world.HEIs in developing countries face additional challenges in implementing e-learning in their curriculum whilst striving to provide the "education basics". These challenges include poor infrastructure, limited space and, limited number of qualified lecturers.

Generally speaking, universities seem to be struggling to adapt to the transition from the industrial revolution era into the new era of information technology in which demographic, technological, and economic pressures are forcing HEIs to change in a way that was never deemed possible [1], [2]. Duderstadt [3] stated that higher education is facing a future in which stability becomes less important than creativity and flexibility. Hence, continual change will be one of the certainties. Austin et al. [4] stated that there are always concerns regarding the way HEIs respond to such continual change.

Saudi higher education system does not run in isolation from such transitions and has accordingly experienced a number of changes and developments over the past few years. The Saudi Ministry of Higher Education has invested large amount of money into e-learning across the Saudi Kingdom. However, effective adoption and implementation of e-learning across many Saudi HEIs do not seem proportional to the huge government investment in technology in education.

This paper will investigate the potential barriers towards effective adoption and implementation of e-learning by faculty members. To do so, this study will take one of the Saudi universities (targeted university) as a case study to generate understandings towards these potential barriers. This paper will attempt to answer the following research questions:

1) What are the potential barriers experienced by faculty staff members towards effective implementation of 
e-learning in one of the Saudi universities?

2) What type and pattern do such barriers take?

3) What action(s) do these identified barriers suggest?

\section{LITERATURE REVIEW}

In response to the demands of our digital and connected world and globalised market, the Saudi Ministry of Higher Education has been emphasizing e-learning as an essential and innovative development that can neither be ignored nor avoided. An example of this strong emphasis is the establishment of the National Centre of e-Learning and Distance Learning and the National Commission for Academic Accreditation and Assessment in 2006 [5], [6]. National stakeholders at the Saudi Ministry of Higher Education called for a national plan to adopt e-learning in HEIs across the country. The established plan puts great emphasis on the implementation of e-learning and distance education and their prospective applications in Saudi universities [7].

The National Center of e-learning and distance learning, (ELC) was established in late 2006. The center aims to organize the transition towards e-learning in HEIs and prepare e-learning material through its own Learning Management System (LMS) called Jusur, the Arabic translation to bridges in English to highlight the connectedness that e-learning and distance learning bring about. Nine universities, including the targeted university by this study, have already agreed to implement Jusur.

Mirza [8] stated that although a number of Saudi universities have already started transitioning towards e-learning, most of these universities are e-learning practices are limited to capturing the delivered lectures and making it available through the LMS to their full time students on campus. However, with the increased expenditure $(\sim 200$ billion USD) by the Saudi Government on expanding access and transition plans for Saudi universities by 2014 [9], universities' policies are expected to change accordingly to implement e-learning in more effective ways than the current practices.

The process of integrating e-learning into teaching and learning might be a complex procedure which may encounter a number of difficulties which are sometimes called barriers or obstacles towards e-learning integration.Throughout literature, various categories have been argued by researchers to classify the barriers/obstacles towards integrating e-learning into higher education. According to Rogers [1], what stops faculty members from using new technologies is a combination of several factors: socio-cultural related factors (e.g., economics and location), personological related factors (e.g., age, gender, attitudes and beliefs), and the extent of theexposure (including support and training) to new technologies.

Age is believed to be one of the demographic variables that tend to shape educators' perceptions of e-learning. Al-Fadhli [2] conducted a study which indicated that faculty members whose ages were 45 and above were less willing to employ e-learning in their teaching and learning practice; similar outcomes were reported by Al-Sarrini [3]. Conversely, younger faculty members were reported to be more enthusiastic about implementing and using e-learning. Al-Fadhli [2] argued that age is an important independent variable effecting the perception of faculty members towards e-learning. However, Alenezi [4] stated that the reluctant attitude towards e-learning is not necessarily related to age but to a combination of factors including technical competencies and exposure to e-learning.

Gender is a factor that is believed to be of an influence on faculty member attitudes towards e-learning, where several studies indicated that female faculty members held more positive views towards e-learning and they showed more willingness to implement it when compared to their male counterparts [5], [6]. However, a study conducted by Wong \&Atan [7] revealed that equal levels of positive perceptions towards e-learning were reported by both genders.

O'Donnell [8] reported that faculty members' perceptions towards technology integration in their everyday teaching and learning practice are highly influenced by demographic factors like age, gender, position, et al. Muilenburg \& Berge [9] reported a large number of studies made in the area of technology integration barriers revealed significant differences in learning, experience, motivation, and attitude in relation to gender, age and ability to use technology. Al-Senaidi et al.'s [10] findings showed that male faculty members with less e-learning usage, perceived more barriers regarding the lack of computing equipment and were in more disbelief of e-learning benefits than female faculty members.

Educational level and background is another possible factor that might influence- but to a lesser extent- the attitude towards e-learning. Agboola's study [11] showed that faculty members with masters or doctoral degrees had no significant differences in their perception towards e-learning. Same finding were reported by a study conducted in another Arabian neighbouring country [12]. However, Al-Sarrani's research [3] found that the level of education slightly influenced faculty members' perceptions of e-learning.

Barriers towards successful and efficient adoption of technology seems to comprise internal and external sources as perceived by Rogers [1]. Internal sources are related to the faculty members' attitudes toward technology and their actual competency level of the emerging technologies. On the other hand, external sources include: the inaccessibility and unavailability of the needed software and hardware, the lack of associated technical and institutional support, and finally the lack of time and funding across internal and external sources.

First order and second order barriers is another approach towards classifying barriers towards e-learning as asserted by Butler \& Sellbom [13] and Snoeyink \& Ertmer [14]. Extrinsic barriers to technology integration (first order barriers) include the lack of access to hardware and software, insufficient time, and administrative support. On the other hand, intrinsic barriers (second order barriers) are related to faculty members' beliefs about teaching and learning, attitudes towards technology, and their resistance to change.

Ertmer [15] indicated that first order barriers are usually described as resources related barriers, thus they are easy to measure and eliminate once funding is available. Furthermore, Sandholtz, Ringstaff \& Dwyer [16] noted that the elimination of first order barriers allows second order 
barriers to appear. They added that massive introduction of technology, most of the time, forces faculty members back to their initial teaching mode. They will have to deal with issues like classroom management, role definition, and lesson planning and designing. On the other hand, Kerr [17] noted that because second order barriers are linked to faculty members' underlying beliefs about teaching and learning, these barriers are not easily identified and revealed. These barriers are often more challenging to overcome than first order barriers.

Further classification of barriers has been made by Jones [18]. This classification groups barriers according to teacher-level (individual barriers) versus institutional-level (school-level barriers). The individual level barriers include lack of confidence, lack of time, and resistance to change. The institutional level barriers cover lack of effective training and lack of access to resources.

Numerous studies have found a relationship between faculty members' attitudes towards technology and their actual use of e-learning tools, where faculty members with positive attitude towards technology are more likely to use e-learning tools in their everyday practice than those who hold negative attitudes [19]-[21].

Several studies illustrated that the lack of technical support is a main barrier to adopting e-learning [10], [22]-[27]. Lewis [28] cited that without sufficient technical support inside and outside classrooms, faculty members cannot be expected to overcome the barriers preventing them from employing e-learning. Bingimlas [29] reported that several recent studies indicates that many faculty members have both competence and confident in using e-learning tools; however, they still make little or no use of these available technologies because they hardly have enough time. A number of researchers identified lack of time and concerns about workloads as barriers towards e-learning in HEIs [22], [23], [26], [30], [31].

Al-Oteawi [32] argues that achieving successful integration of technology into education requires quality staff professional development programs. A number of studies reported inadequacy of professional development programs as one of the barriers towards e-learning integration in higher education [13], [25], [26], [31], [33]. Al-Mohaissin's [34] and Johnson et al. [35] reported poor compatibility which exists between staff training and the available software and hardware as one of the main barriers towards e-learning integration. Keengwe et al. [36] stated that professional staff members need to strive to provide faculty members with extensive and quality professional development programs to ensure effective integration of new technologies. The poor ICT literacy skills by some faculty staff members are attributed to a number of factors including lack of funding, low administrative support, and paucityof formal digital fluency agenda [35]. The content of effective professional development programs as argued by Keengwe et al. [36] should be: a) pedagogically connected to students' learning, b) associated by adequate resources, c) built in evaluation system, d)continuouslyfunded, e) allocated sufficient time, f) associated with technical and administrative support, g) sustained as anon-going process, h) oriented towards being practical hands-on technology sessions, I) tailored to all staff members including newly appointed ones, and k) designed to offer curriculum specific support to integrate specific applications.

Studies have identified a range of factors as barriers to adopting e-learning in higher education. This paper will investigate all the fifteen literature-reported barriers towards adopting e-learning (Table I). In addition this research will include a potential barrier which might be relevant to the Saudi context and non-English speaking countries, namely the lack of adequate English language proficiency.

TABLE I: GROUPS OF PERCEIVED BARRIERS TO ADOPTING E-LEARNING (COMPILED FROM LITERATURE REVIEW)

\begin{tabular}{ll}
\hline Barriers classification & Items or barriers included in this category \\
Internal sources & $\begin{array}{l}\text { Concern about the quality of e-courses, } \\
\text { Lack of incentives to use e-learning, } \\
\text { Self-intimidated by technology, Lack of } \\
\text { adequate English proficiency , No role } \\
\text { models to follow }\end{array}$ \\
& $\begin{array}{l}\text { Concern about access to students, Lack of } \\
\text { training on e-learning, Poor Internet access } \\
\text { and networking in the university, Lack of } \\
\text { technical support in the university, Lack of } \\
\text { instructional design support for e-learning, } \\
\text { Lack of institutional policy for e-learning, } \\
\text { Inadequate availability of hardware and } \\
\text { software, Concern about security issues on } \\
\text { Internet, Lack of credit towards promotion }\end{array}$
\end{tabular}

Across Internal and

External Sources Concern about workload, Lack of time to Barriers develop e-courses

\section{Methodology}

\section{A. Data Gathering}

214 questionnaires were electronically collected. Questionnaires were designed through the Survey Monkey, an online survey software and questionnaire tool. Questionnaires were sent to all 537 faculty members through the targeted university's global email list. The sent emails contained two direct links to the survey in both the Arabic and English languages in addition an information sheet and a consent letter in both languages were attached.Data collected through questionnaires mainly focused on participants' perceived barriers towards e-learning based on Table I. The structure and content of the questionnaire have been already tested and validated by nine experts [25]. A five-point Likert scale was used to measure attitudes and perceptions towards e-learning and any associated barrier towards implementing it. The Likert scale required the participants to respond to close-ended statements by placing their response on a 'strongly agree' to 'strongly disagree' scale in a direct, self-reported method. The five-point scale has a Cornbach-alpha co-efficient of 0.81 indicating high internal consistency of items [25].

\section{B. Data Analysis}

A number of inferential tests set for statistical analysis were conducted for analysis of variance. Multivariate Analysis of Variance (MANOVA) was employed. This 
approach facilitated comparison across various demographic groups, namely, age, gender, and discipline. Rank Order Analysis were used for identifying the order of the reported barriers. The parameters used in the formulas for the MANOVA comprised of:

- Demographics: gender, age, position, and discipline, where comparisons took place across four various disciplines (faculties): Economics and Business Administration, Computer Science and Engineering, Arts and Humanities, and Sciences (including Medical Sciences).

- Dependent variables: The frequency of technology use.

- Independent variables: The extent of the perceived barriers

1) Internal sources barriers: concerns about the quality of e-courses, lack of incentives to adopt e-learning, self-intimidated by technology, lack of adequate English proficiency, and no role models to follow

2) External sources barriers: concerns relating to access to students' lack of training on e-learning, poor internet network, lack of IT support, lack of instructional design support for e-learning, lack of institutional policy for e-learning, inadequate availability of hardware and software, etc.

3) Across internal and external sources: concern about faculty workload, and lack of time to develop e-courses.

\section{RESULTS}

MANOVA was conducted to measure the differences of faculty members perceived barriers' sub-scale groups (internal resources, external resources, and across internal and external resources barriers) to adopting e-learning based on their demographic (gender, age, position, discipline). Result indicated a significant difference for gender Wilks' Lambda $\lambda=.951, F(3,159)=2.725, p<.046, \eta^{2}=.049$. However, there weren't significant differences between faculty members' sub-scale groups to adopting e-learning based on the other demographic factors, namely age, position, and discipline.

TABLE II: SUB-SCALE GROUPS OF PERCEIVED BARRIERS TO ADOPTING

\begin{tabular}{llll}
\multicolumn{5}{c}{ E-LEARNING } \\
\hline & $N$ & Mean & S.D. \\
\hline External Barriers & 214 & 32.4206 & 6.17878 \\
Internal Barriers & 214 & 14.0169 & 4.16472 \\
Across Internal and External & 214 & 6.3380 & 2.53752 \\
Barriers & 214 & & \\
Valid N (listwise) & & & \\
\hline
\end{tabular}

Table II reveals that faculty members cited external sources barriers as the most significant to hindering their e-learning implementation in the targeted university; $M=32.42, S D=6.17$. Internal sources barriers were the second highest; $M=14.01, S D=4.16$. Across internal and external sources were the least cited barriers; $M=6.33$, $S D=2.53$.

Female faculty members perceived less barriers in two out of the three sub-scale barriers groups, namely for internal resources $(M=13.59, S D=4.18)$ and across internal and external resources $(M=5.99, S D=2.70)$.
The significant difference between participants' perceived barriers based on gender complements Al-Senaidi et al.'s[10] findings which showed that male faculty members with less e-learning usage, perceived more barriers than their female counterparts mainly in relation to the lack of computing equipment and non-convincement in e-learning benefits. Hence, findings from this study support that gender is a key factor in appreciating and using e-learning as the result indicated a significant difference for gender: Wilks' Lambda $\lambda=.951, F(3,159)=2.725, p<.046, \eta^{2}=.049$.

The order of the perceived barriers towards e-learning based on Rank Order Analysis is illustrated in Table III. The top four barriers in descending order were: poor internet access and networking in the university $(M=4.20, S D=1.07)$, lack of training on e-learning $(M=4.13, S D=.979)$, lack of technical support in the university $(M=4.09, S D=1.064)$, andinadequate availability of hardware and software $(M=3.97, S D=1.154)$. The least four cited barriers to adopting e-learning at the targeted university in ascending order were: self-intimidated by technology $(M=2.14$, $S D=1.188)$, concern about the quality of e-courses $(M=2.62$, $S D=1.225)$, lack of role models to follow $(M=2.63$, $S D=1.310$ ), and concern about security issues on the internet $(M=2.85, S D=1.284)$. As displayed in Table III the top five barriers were all external sources barriers.

TABLE III: PERCEIVED BARRIERS TOWARDS E-LEARNING

\begin{tabular}{|c|c|c|c|c|c|}
\hline & $N$ & Min & $\operatorname{Max}$ & Mean & S.D. \\
\hline $\begin{array}{l}\text { Poor Internet access and } \\
\text { networking }\end{array}$ & 214 & 1 & 5 & 4.20 & 1.074 \\
\hline Lack of training on e-learning & 214 & 1 & 5 & 4.13 & .979 \\
\hline $\begin{array}{l}\text { Lack of technical support in the } \\
\text { university }\end{array}$ & 214 & 1 & 5 & 4.09 & 1.064 \\
\hline $\begin{array}{l}\text { Inadequate availability of hardware } \\
\text { and software }\end{array}$ & 214 & 1 & 5 & 3.97 & 1.154 \\
\hline $\begin{array}{l}\text { Lack of institutional policy for } \\
\text { e-learning }\end{array}$ & 214 & 1 & 5 & 3.69 & 1.046 \\
\hline $\begin{array}{l}\text { Lack of adequate English language } \\
\text { proficiency }\end{array}$ & 214 & 1 & 5 & 3.36 & 1.393 \\
\hline $\begin{array}{l}\text { Lack of instructional design support } \\
\text { for e-learning }\end{array}$ & 214 & 1 & 5 & 3.32 & 1.176 \\
\hline Concern about faculty workload & 214 & 1 & 5 & 3.28 & 1.355 \\
\hline Lack of incentives to use e-learning & 214 & 1 & 5 & 3.25 & 1.318 \\
\hline Lack of credit towards promotion & 214 & 1 & 5 & 3.25 & 1.242 \\
\hline Lack of time to develop e-courses & 214 & 1 & 5 & 3.06 & 1.379 \\
\hline Concern about access to students & 214 & 1 & 5 & 2.91 & 1.215 \\
\hline $\begin{array}{l}\text { Concern about security issues on } \\
\text { Internet }\end{array}$ & 214 & 1 & 5 & 2.85 & 1.284 \\
\hline No role models to follow & 214 & 1 & 5 & 2.63 & 1.310 \\
\hline $\begin{array}{l}\text { Concern about the quality of } \\
\text { e-courses }\end{array}$ & 214 & 1 & 5 & 2.62 & 1.225 \\
\hline Self-intimidated by technology & 214 & 1 & 5 & 2.14 & 1.188 \\
\hline Valid N (listwise) & 214 & & & & \\
\hline
\end{tabular}

The top four barriers revealed in the quantitative analysis werecited as top barriers in a number of studies, namely, poor internet access and networking in the university [10], [25], lack of training on e-learning [13], [25], [26], [31], lack of technical support in the university[10], [22], [24]-[26], [30], and inadequate availability of hardware and software [10], [25], [30], [37].

External sources barriers which are also termed resources barriers according to Ertmer [15] can be eliminated if funding is available. Surprisinglythe targeted university was one of the Saudi HEIs which was selected and funded by the Saudi Ministry of Higher Education as a pilot institute trialling e-learning and the national LMS: Jusur [38]. Despite the 
expected provided technical and financial support, faculty members at the targeted university are still experiencing significant resources (external) barriers as evident bythe top cited barriers (Table III). This prompts for a deeper inquiry into the reasons behind the predominance of external barriers despite government support.

\section{CONCLUSION}

Whilst there is no consensus that perceived barriers towards e-learning are gender specific, this study found that female faculty members perceived less e-learning barriers than their male counterparts. In the context of this study and despite government's support and funding, external sources barriers were predominately reported in the targeted universities which suggests that-in addition to fundingstrategic policies by the HEIs themselves are required to promote ICT in education (ICTE) and e-learning. Such policies are expected to promptly ensure that high-speed internet access and reliable networks are available at the HEI. In addition, adequate and continuous professional development programs on e-learning and ICTE should be made available. The policies needs to support and expand an IT service department which overlooks and supports all IT-transactions taking place in the HEI and make sure that up-to-date software and hardware are available for all staff members. Overcoming external sources barriers is mandatory to progress to overcoming the remaining barriers so that the focus is more on thepedagogical dimensions and opportunities of e-learning rather than on the logistics.

\section{ACKNOWLEDGMENT}

M. A. Al Gamdi would like to thank Al Baha University for giving him the chance to pursue his studies for the $\mathrm{PhD}$, thank you for your generous sponsorship, continuous support.

\section{REFERENCES}

[1] P. Rogers, "Barriers to adopting emerging technologies in education," Journal of Educational Computing Research, vol. 22, pp. 455-472, 2000.

[2] S. Al-Fadhli, "Instructor Perceptions of e-learning in an Arab Country: Kuwait University as a case study," E-Learning and Digital Media, vol. 6, pp. 221-229, 2009.

[3] N. Al-Sarrani, "Concerns and professional development needs of science faculty at taibah university in adopting blended learning," 2010.

[4] A. M. Alenezi, "Faculty members' perception of e-learning in higher education in the Kingdom of Saudi Arabia (KSA)," Texas Tech University, 2012

[5] MOHE, "About Saudi Government Universities," Saudi Ministry of Higher Education 2/3/2014.

[6] E.-R. Yasmine, "Saudi Arabia continues expanding higher education," The Chronicle of Higher Education, vol. 53, p. A.51, 2007.

[7] S. L. Wong and H. Atan, "Gender differences in attitudes towards information technology among Malaysian student teachers: A case study at Universiti Putra Malaysia," Educational Technology \& Society vol. 10, pp. 158-169, 2007.

[8] J. O'Donnell, "Teacher perception of their e-learning needs to integrate e-learning into classroom instruction," Doctoral dissertation, University of Southern California at Los Angeles, 1991.

[9] L. Y. Muilenburg and Z. L. Berge, "Student barriers to online learning: A factor analytic study," Distance Education, vol. 26, pp. 29-48, 2005

[10] S. Al-Senaidi, L. Lin, and J. Poirot, "Barriers to adopting technology for teaching and learning in Oman," Computers \& Education, vol. 53, pp. 575-590, 2009.
[11] A. Agboola, "Assessing the awareness and perceptions of academic staff in using e-learning tools for instructional delivery in a post-secondary institution: A case study," The Innovation Journal: The Public Sector Innovation Journal, vol. 11, pp. 2-12, 2006.

[12] M. A. Qudais, M. Al-Adhaileh, and A. Al-Omari, "Senior faculty members' attitudes in Jordanian universities towards using Information and communication technology," Int. Arab J. e-Technol., vol. 1, pp. 135-141, 2010.

[13] D. L. Butler and M. Sellbom, "Barriers to adopting technology for teaching and learning," Educause Quarterly, vol. 25, pp. 22-28, 2002.

[14] R. Snoeyink and P. A. Ertmer, "Thrust into technology: How veteran teachers respond," Journal of Educational Technology Systems, vol. 30, pp. 85-111, 2002.

[15] P. A. Ertmer, "Addressing first-and second-order barriers to change: Strategies for technology integration," Educational Technology Research and Development, vol. 47, pp. 47-61, 1999.

[16] J. Sandholtz, C. Ringstaff, and D. Dwyer, Teaching with Technology: Creating Student Centered Classrooms, New York: Teachers College Press, 1997.

[17] S. Kerr, Visions of Sugarplums: The Future of Technology, Education, and the Schools, Chicago: University of Chicago Press., 1996.

[18] A. Jones, "A review of the research literature on barriers to the uptake of ICT by teachers," Coventry: Becta, 2004.

[19] J. D. Shapka and M. Ferrari, "Computer-related attitudes and actions of teacher candidates," Computers in Human Behavior, vol. 19, pp. 319-334, 2003.

[20] T. Teo et al., "Understanding pre service teachers' computer attitudes: applying and extending the technology acceptance model," Journal of Computer Assisted Learning, vol. 24, pp. 128-143, 2008.

[21] J. Van Braak, "Individual characteristics influencing teachers' class use of computers," Journal of Educational Computing Research, vol. 25, pp. 141-157, 2001

[22] T. A. Almuqayteeb, "Attitudes of female faculty toward the use of computer technologies and the barriers that limit their use of technologies in girls' colleges in saudi arabia," Ph.D, Department of Instructional Systems and Workforce Development, Mississippi State University, 2009.

[23] A. E. S. Alwani and S. Soomro, "Barriers to effective use of information technology in science education at Yanbu Kingdom of Saudi Arabia," InTech, 2010.

[24] J. F. Chizmar and D. B. Williams, "What do faculty want?" Educause Quarterly, vol. 24, pp. 18-24, 2001.

[25] S. Panda and S. Mishra, "E-learning in a mega open university: Faculty attitude, barriers and motivators," Educational Media International, vol. 44, pp. 323-338, 2007.

[26] K. Schoepp, "Barriers to technology integration in a technology-rich environment," Learning and Teaching in Higher Education: Gulf Perspectives, vol. 2, pp. 1-24, 2005.

[27] Y. Alharbi, "A study of the barriers and attitudes of faculty and administrators toward implementation of online courses (Saudi Arabia)," University Of Northern Colorado. DAI-A, vol. 63, p. 2513, 2003.

[28] S. Lewis, "Enhancing teaching and learning of science through use of ICT: Methods and materials," School Science Review, vol. 84, pp. 41-51, 2003

[29] K. A. Bingimlas, "Barriers to the successful integration of ICT in teaching and learning environments: A review of the literature," Eurasia Journal of Mathematics, Science \& Technology Education, vol. 5, pp. 235-245, 2009.

[30] A. E. S. Al-Alwani, "Barriers to integrating information technology in Saudi Arabia science education," 2005

[31] E. Schieman and R. Fiordo, "Barriers to adoption of instructional communications technology in higher education," presented at the Australian Communication Conference, Melbourne, 1990.

[32] S. Al-Oteawi, "The perception of administrators and teachers in utilizing information technology in instruction, administrative work, technology planning and staff development in Saudi Arabia," Doctoral dissertation, Ohio University, 2002.

[33] H. S. A. Al-Ghonaim, "Attitudes, barriers and incentives of Saudi college instructors and administrators toward implementation of online instruction," The University of Kansas, 2006.

[34] I. Al-Mohaissin, "Instructions into secondary schools science teaching in saudi arabia: teachers' views, some problems and possible solutions," Doctoral dissertation, University of Hull, 1993.

[35] L. Johnson et al., "Horizon Report: 2014 Higher Education," 2014.

[36] J. Keengwe, G. Onchwari, and P. Wachira, "Computer technology integration and student learning: Barriers and promise," Journal of Science Education and Technology, vol. 17, pp. 560-565, 2008. 
[37] A. Byers, "Communities address barriers to connectivity," Rural Clearinghouse Digest, vol. 3, p. 8, 1996.

[38] MOHE. (2011). About the National Centre of e-Learning \& Distance Learning in Saudi Arabia. [Online]. Available: http://www.mohe.gov.sa/ar/Ministry/Deputy-Ministry-for-Planning-a nd-Information-affairs/Pages/edition.aspx

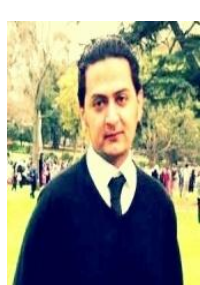

Mohammad Ali Al Gamdi was born in Mecca, Saudi Arabia in December 1980. He is currently a $\mathrm{PhD}$ candidate at Victoria University, Australia. In 2008, Al Gamdi completed his master degree in computer assisted language learning at Melbourne University, Melbourne, Australia. He worked as a teacher in Saudi Ministry of Education for six years. Al Gamdi was a lecturer at $\mathrm{Al}$ Baha University, Saudi Arabia for two years before gaining a scholarship form $\mathrm{Al}$ Baha University for $\mathrm{PhD}$ program. His main focus as a researcher is e-learning and language learning.

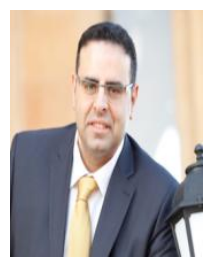

Ahmad Samarji is an academic at the College of Education, Victoria University Melbourne. Dr Samarji is interested in education, including ICT in education (ICTE) and e-learning, STEM education, forensic science and forensic medicine education, internationalisation of the curriculum, higher education role in knowledge management. 